\title{
Hamartin and Tuberin Expression in Human Tissues
}

Michael W. Johnson, B.S., Christopher Kerfoot, Ph.D., Theodore Bushnell, M.D., Marissa Li, M.D., Harry V. Vinters, M.D.

UCLA Interdepartmental Program in Neuroscience (MWJ), Department of Pathology and Laboratory Medicine (Neuropathology; MWJ, CK, TD, ML, HVV), and Brain Research Institute, Neuropsychiatric Institute and Mental Retardation Research Center (HVV), UCLA Medical Center, Los Angeles, California

Tuberous sclerosis (TSC) is a bigenic autosomal dominant disease caused by mutations in one of two tumor-suppressor genes, TSC1 and TSC2, resulting in benign hamartomas and low grade neoplasms in multiple organs including brain, heart, kidney, and skin. We report the results of an immunohistochemical study of the expression of the TSC gene products, tuberin and hamartin, in multiple tissues obtained at autopsy from 12 non-TSC affected patients ranging in age from 20 weeks gestation to 8 years, and surgical specimens from some organs. Tuberin and hamartin are expressed and are colocalized in most tissues. Contrary to a previous report, immunostaining with our antisera detected hamartin in liver, small and large intestine, prostate, and testes. We did not detect significant developmental differences in tuberin or hamartin expression in comparable tissues from patients of different ages. Although tuberin and hamartin colocalize in most tissues and cell types, we provide data that hamartin is more abundantly expressed than tuberin in cells within some tissues including the distal nephron and a population of cells of the endocrine pancreas. These data support the hypothesis that hamartin and tuberin interact and may function together in many tissues where they are co-expressed, but also suggest that hamartin has a discrete and specialized function in certain cell types.

KEY WORDS: Hamartin, Immunohistochemistry, TSC1, TSC2, Tuberin, Tuberous sclerosis. Mod Pathol 2001;14(3):202-210

Copyright (C) 2001 by The United States and Canadian Academy of Pathology, Inc.

VOL. 14, NO. 3, P. 202, 2001 Printed in the U.S.A

Date of acceptance: December 4, 2000.

Address reprint requests to: Harry V. Vinters, Department of Pathology and Laboratory Medicine, Section of Neuropathology, UCLA Medical Center, CHS 18-170, Los Angeles, CA 90095-17321; e-mail: hvinters@mednet.ucla.edu; fax: 310-206-8290.
Tuberous sclerosis (TSC) is an autosomal-dominant disorder characterized by hamartomatous malformations and low-grade neoplasms in various organs, including the brain, kidney, skin and heart. Common hamartomas associated with TSC include facial angiofibroma, cerebral cortical tuber, subependymal nodules, and giant-cell astrocytomas (SEGAs); retinal astrocytoma, cardiac rhabdomyoma, and renal angiomyolipoma $(1,2)$. Individuals with TSC are at high risk for developing renal tumors, including renal cell carcinoma and angiomyolipoma, early in life (3).

TSC has been linked to two separate loci. TSC2 on Chromosome $16 \mathrm{p} 13.3$ produces a $5.5-\mathrm{kb}$ transcript that encodes the $\sim 180-\mathrm{kD}$ protein tuberin; TSC1 on $9 q 34$ produces an $8.6-\mathrm{kb}$ transcript that encodes the $\sim 135$-kD protein hamartin $(4,5)$. Tuberin contains a 58-amino acid region of homology to Rap1GAP and has specific GTPase-activating protein (GAP) activity in vitro for Rapla (6). In addition, yeast two-hybrid analysis has identified a region of tuberin near the C-terminus and distinct from the region of GAP homology that binds to rabaptin-5 and stimulates GTPRab-5 hydrolysis and a reduction in the rate of fluid-phase endocytosis (7). Inactivation of the TSC2 gene in cultured cells causes cytoplasmic localization and inactivation of the cyclin-dependent kinase inhibitor p27 (8). The exact role of these interactions-or disruption of them-in disease states is not yet known. In addition to data supporting a functional interaction between hamartin and tuberin (9), recent evidence suggests that hamartin regulates cell adhesion via its interaction with ezrin-radixin-moesin (ERM) proteins and activation of a Rho-mediated signaling pathway (10). Loss of heterozygosity at TSC1 and TSC2 chromosomal regions in TSC-associated hamartomas suggests that both proteins act as tumor suppressors $(11,12)$.

The tissue and cell-type distribution of the TSC2 transcript and tuberin have been reported in organs of non-TSC-affected humans and rats (Tsc2; 1316). In addition, the expression of hamartin in nor- 


\begin{tabular}{|c|c|c|c|}
\hline Case \# & Age & PMI (h) & Tissues Available* \\
\hline 1 & 20 wk of gestation & 9 & A, H, K, L, Lv, M, S, Th \\
\hline 2 & 21 wk of gestation & 69 & L, Lv, Pl, S, Th \\
\hline 3 & 25 wk of gestation & 6 & L, Lv, GI, H, S \\
\hline 4 & 25 wk of gestation & 18 & L, Lv, Pl, S, Th \\
\hline 5 & $1 \mathrm{~d}$ & 10 & A, GI, H, K, L, Lv, M, P, Pi, S, T, Th \\
\hline 6 & $4 \mathrm{~d}$ & 72 & GI, K, L, Lv, S, Th \\
\hline 7 & $1.5 \mathrm{mo}$ & 8 & A, H, K, L, Lv, Ly, M, P, S, Thr \\
\hline 8 & 3 mo & 14 & GI, H, K, L, Lv, Ly, P, S, T \\
\hline 9 & 4 mo & 0.5 & Lv, M, P, Th, Thr \\
\hline 10 & $1 \mathrm{y}$ & 34 & A, K, L, Lv, Ly, M, P, S, Th, Thr \\
\hline 11 & $4.5 \mathrm{y}$ & 50 & A, H, K, L, Lv, Ly, S \\
\hline 12 & $8 \mathrm{y}$ & 12 & GI, H, K, L, Lv, Pi, S, T \\
\hline
\end{tabular}

$\mathrm{PMI}=$ postmortem interval (approximate) from death to removal of organs/tissues.

${ }^{*} \mathrm{~A}=$ adrenal; $\mathrm{GI}=$ small and/or large intestine; $\mathrm{H}=$ heart (myocardium); $\mathrm{K}=$ kidney; $\mathrm{L}=$ lung; $\mathrm{Lv}=$ liver; $\mathrm{Ly}=$ lymph node; $\mathrm{M}=$ striated muscle; $\mathrm{P}=$ pancreas; $\mathrm{Pi}=$ pituitary; $\mathrm{Pl}=$ placenta; $\mathrm{S}=$ spleen; $\mathrm{Th}=$ thymus; $\mathrm{Thr}=$ thyroid; $\mathrm{T}=$ testis.

mal human tissues has recently been described (17). Here, we report the tissue and cell-type expression of hamartin as compared with that of tuberin in autopsy tissues from 12 non-TSC affected human, ranging in age from 20 weeks' gestation to 8 years, and from selected normal tissues obtained at surgery.

\section{MATERIALS AND METHODS}

\section{Tissue}

Paraffin-embedded autopsy tissue from 12 nonTSC-affected patients ranging in age from 20 weeks gestation to 8 years were used for this study. Cases were chosen such that a developmental study of the expression of tuberin and hamartin in comparable viscera could be performed on most tissues. Available autopsy tissues from each patient are listed in Table 1. In addition to autopsy tissues, all antisera were used for immunohistochemical staining of surgical specimens, including colon, kidney, liver, prostate, and pancreas. Description of the tissues studied and reasons for their removal are listed in Table 2.

\section{Antisera}

Polyclonal antisera recognizing amino acids (a.a.) 1463-1484 ( $\alpha \mathrm{p} 3$ tuberin antiserum) and 1787-1806 ( $\alpha$ p1 tuberin antiserum) of tuberin (4) and a.a. $671-$ 690 (671 hamartin antiserum) of hamartin (5) were prepared and affinity purified as described elsewhere (18). Polyclonal antiserum recognizing a.a. 1107-1130 (C-term hamartin antiserum) of hamartin, which has already been characterized (18), was used for immunoblots and immunohistochemistry on tissues from some cases.

\section{Immunohistochemistry}

Paraffin-embedded, formalin-fixed tissues removed at autopsy or surgery were sectioned at 6 $\mu \mathrm{m}$, dewaxed, and rehydrated through graded ethanols. Rehydrated sections were subjected to antigen retrieval in $0.1 \mathrm{~m}$ sodium citrate, $\mathrm{pH} 6.0$, for 30 minutes at $100^{\circ} \mathrm{C}$. Endogenous peroxidase activity was quenched by incubating with $3 \%$ hydrogen peroxide in phosphate-buffered saline for $20 \mathrm{~min}$ utes. Blocking was performed at room temperature with $5 \%$ bovine serum albumin $/ 5 \%$ normal goat serum for 1 hour. Sections were incubated with dilute primary antisera overnight at room temperature. Three antisera were used at dilutions of $1 / 150-1 / 200(\sim 6 \mu \mathrm{g} / \mathrm{mL})$, and C-term hamartin antiserum was used at a dilution of $1 / 500$. These dilutions were chosen after a small pilot study performed to determine the optimal dilutions and conditions for producing qualitatively comparable staining intensities on most tissues with all antisera. Sections were subsequently incubated in antirabbit IgG antiserum (diluted 1/500 in blocking solution) for 1 hour at room temperature. Detection was performed using the ABC kit (Vectastain) and diaminobenzidine (3,3'-diaminobenzidine). Some tissues were counterstained with hematoxylin. Peptide preabsorption of the 671 hamartin and $\alpha \mathrm{p} 3$ tuberin antisera, before their use, was performed in some immunohistochemical runs as a control for antibody specificity. In these studies, antisera and excess peptide $(20 \mu \mathrm{g}$ of peptide per microgram of antisera) were diluted in $500 \mu \mathrm{L}$ of phosphatebuffered saline or blocking solution and incubated at $4^{\circ} \mathrm{C}$ for 2 hours before application to slides.

TABLE 2. Description of Surgical Specimens

\begin{tabular}{cll}
\hline Case \# & Tissue & \multicolumn{1}{c}{ Diagnosis } \\
\hline 13 & Prostate & Prostatic adenocarcinoma \\
14 & Pancreas & Serous microcystic adenoma \\
15 & Prostate & Prostatic adenocarcinoma \\
16 & Kidney & Renal cell carcinoma \\
17 & Colon & Gunshot wound \\
18 & Liver & Chronic hepatitis \\
19 & Prostate & Prostatic adenocarcinoma \\
\hline
\end{tabular}




\section{Immunoblotting}

Autopsy tissues from two patients (tissues processed upon removal) and frozen autopsy tissues from one patient-including adrenal, brain, heart, kidney, liver, ovary, pituitary, skeletal muscle, stomach, spleen, and thyroid-were homogenized with a PT10/35 model Polytron (Brinkmann Instruments) in a buffer containing $0.32 \mathrm{M}$ sucrose, $5 \mathrm{~mm}$ Hepes pH 7.4, 3 mm EGTA, 0.5 mm magnesium sulfate, and complete protease inhibitors (Roche, Indianapolis, IN). All tissues were collected within 10 to 15 hours of death. Total protein concentration was determined with the Bio-Rad Protein Assay (Bio-Rad Hercules, California). One hundred micrograms of total protein of each homogenate were resolved on $4 \%-15 \%$ polyacrylamide gels and transferred to PVDF for immunoblotting. Blots were incubated with $\mathrm{C}$-term hamartin at a dilution of $1 / 2000(0.5 \mu \mathrm{g} / \mathrm{mL})$ for 5 hours. Immunolabeling was detected, after incubation with a secondary anti-rabbit IgG HRP-conjugated antibody for 1 hour, with Amersham electrochemiluminescence reagents (Amersham, Piscataway, New Jersey).

\section{RESULTS}

\section{Immunoblotting}

The 671 and C-term hamartin antisera $(18,19)$ detect single bands at approximately $140 \mathrm{kDa}$, and the $\alpha \mathrm{p} 1$ and $\alpha \mathrm{p} 3$ tuberin antisera detect single bands at approximately $190 \mathrm{kDa}$ on Western blots of NT2 cell lysates (Fig. 1, A-C; right-hand panels),
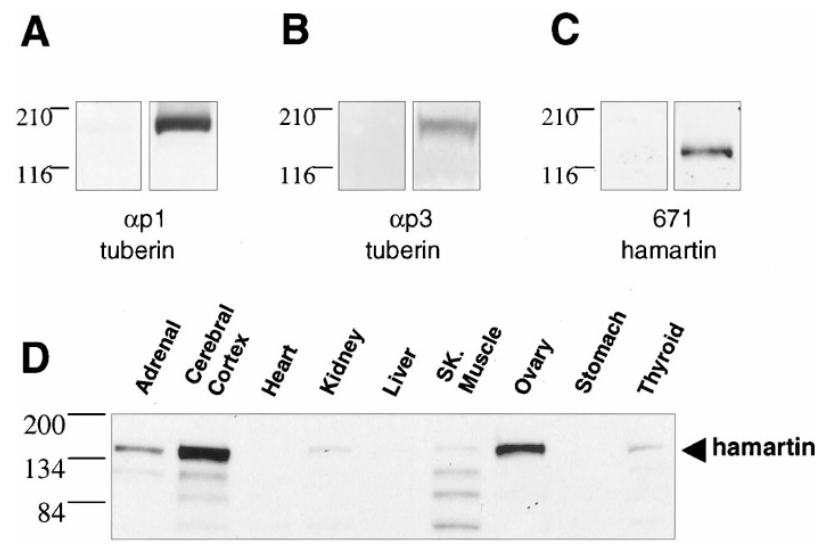

FIGURE 1. Western blots of cultured cells and human tissues with tuberin and hamartin antisera. A, B) $\alpha \mathrm{p} 1$ tuberin (A) and $\alpha \mathrm{p} 3$ antisera (B) detect bands at approximately $190 \mathrm{kDa}$, the predicted size of tuberin, on blots of NT2 cell lysates (right-hand panels). C) 671 hamartin antiserum detects a single band at approximately $140 \mathrm{kDa}$, the predicted size of hamartin, in NT2 cell lysate (right panel). C-term hamartin antiserum, also used in this study, was described previously (18). A-C) Preabsorption of the three antisera with their corresponding peptides abolishes staining (left panels in A-C). D) C-term hamartin antisera detects hamartin (arrowhead) in adrenal gland, cerebral cortex, kidney, skeletal muscle, ovary, and thyroid gland in addition to lower molecular-weight bands probably representing degradation products in several of these tissues. lysates of multiple human and rat cell cultures, and human cerebral cortical surgical and some autopsy tissue homogenates (complete data not shown). Immunoreactivities are blocked by peptide absorption (see Fig. 1, A-C; left-hand panels; 18). Western blots performed for this study with the C-term hamartin antibody detected multiple smaller bands in most of the human autopsy tissues collected in addition to the expected band at $\sim 140 \mathrm{kDa}$ corresponding to hamartin. An immunoblot with C-term hamartin antibody on human tissues from one patient is shown in Figure 1. Because multiple bands are not detected in surgical tissues and fresh cell lysates, the extra bands are most likely due to tissue autolysis before and during autopsy and represent degradation products of the full-size hamartin protein. Hamartin ( $\sim 140-\mathrm{kDa}$ band) is detected in homogenates of adrenal gland, brain, kidney, ovary, pituitary, skeletal muscle, and thyroid gland but not in heart, liver, spleen, or stomach.

\section{Immunohistochemistry}

The tissue and cell-type distributions of hamartin and tuberin immunoreactivity are summarized in Table 3. Although hamartin and tuberin immunoreactivities varied slightly from case to case, there were no significant differences in the expressions of tuberin or hamartin in comparable tissues from patients of different ages. 671 hamartin antiserum and $\alpha \mathrm{p} 3$ tuberin antiserum were used for immunohistochemistry on all 12 cases and the surgical specimens. To verify and strengthen the data from these studies, C-term hamartin antiserum was used on 3 of the 12 autopsy cases and on the surgical specimens. $\alpha \mathrm{p} 1$ tuberin antiserum was used on four cases and the surgical specimens. Staining was nearly identical with either hamartin or tuberin antiserum (data not shown); all photographs shown are of tissues stained with either $\alpha \mathrm{p} 3$ tuberin or 671 hamartin antisera. Peptide absorption of 671 hamartin and $\alpha \mathrm{p} 3$ tuberin antisera were performed on sections of kidney and liver from some cases. Peptide absorption eliminated significant immunoreactivity. Hamartin and tuberin immunoreactivity were localized primarily to the cytoplasm of most cells, but immunohistochemistry with tuberin antisera often also produced strong nuclear and/or perinuclear staining - a result consistent with our immunohistochemical studies of neuroglial cells within TSC-associated cortical tubers (18).

Tuberin and hamartin were found expressed in various human epithelia-including bronchial, gut, glandular epithelia, and renal tubular epitheliasmooth, striated, and cardiac muscle; vascular smooth muscle; and myenteric ganglionic cells. Weak staining throughout lymphatic tissues was produced with our hamartin antisera. Moderate to 


\begin{tabular}{|c|c|c|}
\hline & Hamartin & Tuberin \\
\hline \multicolumn{3}{|l|}{ Adrenal gland } \\
\hline Zona glomerulosa & +++ & ++ \\
\hline Zona fasciculata & +++ & ++ \\
\hline Zona reticularis & +++ & +++ \\
\hline Medulla & ++ & ++ \\
\hline \multicolumn{3}{|l|}{ Gut (small/large intestine and colon) } \\
\hline \multicolumn{3}{|l|}{ Epithelium } \\
\hline Enterocytes & +++ & +++ \\
\hline Goblet cells & +++ & +++ \\
\hline Smooth muscle & +++ & ++ \\
\hline Myenteric plexus & +++ & +++ \\
\hline Heart (cardiac myocytes) & +++ & ++ \\
\hline \multicolumn{3}{|l|}{ Kidney } \\
\hline Glomeruli & 0 & 0 \\
\hline Proximal convoluted tubules & ++ & ++ \\
\hline Loop of henle & $+1++$ & $+1++$ \\
\hline Distal convoluted tubules & +++ & ++ \\
\hline Collecting tubules/ducts & +++ & ++ \\
\hline \multicolumn{3}{|l|}{ Liver } \\
\hline Hepatocytes & ++ & ++ \\
\hline Ductal epithelium & ++ & ++ \\
\hline \multicolumn{3}{|l|}{ Lung } \\
\hline Bronchial epithelium & ++ & ++ \\
\hline Type I \& II pneumocytes & 0 & 0 \\
\hline Smooth muscle & +++ & ++ \\
\hline Lymph node & $0 /+$ & + \\
\hline \multicolumn{3}{|l|}{ Pancreas } \\
\hline Secretory acini & $+1++$ & $+1++$ \\
\hline Islet cells & +++ & $+1++$ \\
\hline Ductal epithelium & ++ & ++ \\
\hline \multicolumn{3}{|l|}{ Pituitary } \\
\hline Anterior pituitary chromophils* & +++ & ++ \\
\hline Anterior pituitary chromophobes & 0 & 0 \\
\hline Posterior pituitary & 0 & 0 \\
\hline \multicolumn{3}{|l|}{ Prostate } \\
\hline Ductal epithelium & $+1++$ & ++ \\
\hline Smooth muscle & +++ & ++ \\
\hline Skeletal muscle & +++ & ++ \\
\hline \multicolumn{3}{|l|}{ Spleen } \\
\hline White pulp & $0 /+$ & $0 /+$ \\
\hline Red pulp & + & ++ \\
\hline \multicolumn{3}{|l|}{ Testes } \\
\hline Seminiferous tubules & ++ & ++ \\
\hline Interstitial cells & ++ & ++ \\
\hline Thymus & 0 & 0 \\
\hline Thyroid & + & + \\
\hline
\end{tabular}

$+++=$ prominent staining; $++=$ moderate $+=$ minimal; $0=$ staining absent.

* Although cellular staining intensities were similar, fewer cells were stained with anti-tuberin.

prominent tuberin expression was found in macrophages throughout various tissues and monocytes of the splenic red pulp and within lymph node.

Tuberin and hamartin immunoreactivity were prominent in the cytoplasm of enterocytes and goblet cells within the mucosal epithelia of the small and large intestine. In addition, there was moderate hamartin staining of submucosal vascular media. Moderate and prominent immunostaining for tuberin and hamartin, respectively, were noted in the circular and longitudinal smoothmuscle layers. Both proteins are expressed abundantly in clusters of ganglion cells in the submucosa and between the two smooth-muscle layers (Fig. 2, A-B).
Hamartin and tuberin are moderately expressed in hepatocytes. Staining was diffusely cytoplasmic, often appearing more robust in periportal hepatocytes. Sinusoidal lining cells appeared negative for both proteins. Moderate immunoreactivity with both antisera was found in epithelium of bilecollecting ducts (Fig. 3, A-B) and hepatic arteries of the portal tracts.

Tuberin and hamartin are moderately expressed in seminiferous tubules in the testes. Both proteins appear to be expressed in many spermatagonia (Fig. 3, C-D); however, some cells of the tubules were not labeled with either antiserum. Tuberin and hamartin are also moderately expressed in interstitial Leydig cells.

All antisera produced negligible staining within glomeruli of the renal cortex. Hamartin immunoreactivity in the cortex was robust within some cells of the distal convoluted tubules (DCT) and collecting tubules but only moderate in the proximal convoluted tubules (PCT). Conspicuous lack of hamartin immunoreactivity was noted within some cells of the DCT (Fig. 4C). Tuberin immunoreactivity, on the other hand, appeared to be expressed more homogeneously throughout proximal and distal tubules (Fig. 4). This finding contradicts a recent report suggesting that hamartin is more widely expressed than tuberin in renal tubules (19). Tuberin and hamartin are both expressed moderately, with some variability in cellular/tubular staining, within descending and ascending segments of the loops of Henle. Moderate or prominent expression of both tuberin and hamartin were found in cortical and medullary ductal epithelia.

The TSC gene products colocalize in many glandular tissues. Hamartin and tuberin are expressed in all layers of the adrenal cortex-with the highest cortical expressions in the zona reticularis-and within clusters of medullary cells. In the anterior pituitary, many cells with extensive cytoplasm were stained with both antisera (see Fig. 5, A-B). However fewer cells of this type were labeled with tuberin antisera. Smaller cells with scant cytoplasm did not appear stained with any antiserum. Negligible immunoreactivity was noted in cells of the posterior pituitary (pars neurosa).

Tuberin is expressed somewhat homogeneously in secretory acini of the exocrine pancreas, islets of Langerhans, and ductal epithelium. Hamartin immunoreactivity, on the other hand, is slightly less prominent in secretory acini but much more robust in a minority of cells often located in the periphery of the endocrine pancreas (see Fig. 5, C-D). Thyroid follicle lining cells are weakly immunoreactive for both proteins (Fig. 5, E-F).

We detected high expression of tuberin and hamartin in prostate gland. Hamartin was very robust in smooth muscle of the stroma, capsule, and 



FIGURE 2. Hamartin and tuberin in small intestine of a 4-day-old, full-term infant. A, B) Hamartin (A) immunoreactivity is prominent in the circular $(\boldsymbol{C M})$ and longitudinal smooth-muscle cell layers $(\boldsymbol{L M})$. Note the expression of hamartin in a cluster of parasympathetic ganglion cells (arrow). Tuberin immunoreactivity (B) is slightly more intense in the ganglion cells (arrow) but much less robust in the smooth muscle layers (250×). C, D) Both hamartin (C) and tuberin (D) are abundantly expressed by cells of the mucosal epithelium $(90 \times)$. Staining appears limited to the cytoplasm of enterocytes and goblet cells. Both proteins are expressed in the walls of submucosal blood vessels-although hamartin expression appears more abundant.

vasculature. Hamartin antisera produced weak to moderate variable staining of ductal epithelium. Tuberin expression was often more prominent in the ductal epithelial cells but less prominent in smooth muscle than was hamartin expression.

In lung, type I and II pneumocytes did not appear to express tuberin or hamartin. Some scattered cells-including macrophages-were immunostained with tuberin antisera. Hamartin staining in these scattered cells was weak but often apparent. Tuberin and hamartin were both moderately expressed by bronchial epithelium. As in other organs, prominent hamartin and minimal to moderate tuberin immunoreactivity were found in vascular smooth muscle.

\section{DISCUSSION}

We have previously reported that hamartin and tuberin are expressed in similar neuronal populations within the human CNS as early as 20 weeks of gestation $(17,20)$. This study was performed in order to compare the expression of the TSC gene products tuberin and hamartin in other human tissues at various prenatal and postnatal ages. Immunohistochemistry was performed with two antisera recognizing distinct peptides of tuberin and two antisera recognizing two distinct peptides of the hamartin protein. Because some of our findings are at variance with data reported previously, we also compared surgical and autopsy specimens from select tissues to control for tissue autolysis. Immunohistochemical patterns of staining in specimens of gut, liver, prostate, pancreas, and kidney removed at surgery were identical to staining patterns in those removed at autopsy. The cellular expression patterns of tuberin and hamartin were also similar in comparable autopsy tissues from our cases ranging in age from 20 weeks of gestation to 8 years of age.

Immunostaining with our antisera suggests that hamartin and tuberin are expressed by the same tissues and cell types, with few variations in the levels of expression. Cellular colocalization of hamartin and tuberin is a logical expectation because the two TSC gene products have been shown to interact (9). However, hamartin is more robustly expressed than tuberin in striated, cardiac, and smooth muscle, distal segments of the nephron, and some cells of the endocrine pancreas.

The most apparent differences in tuberin versus hamartin immunoreactivity were those found in 

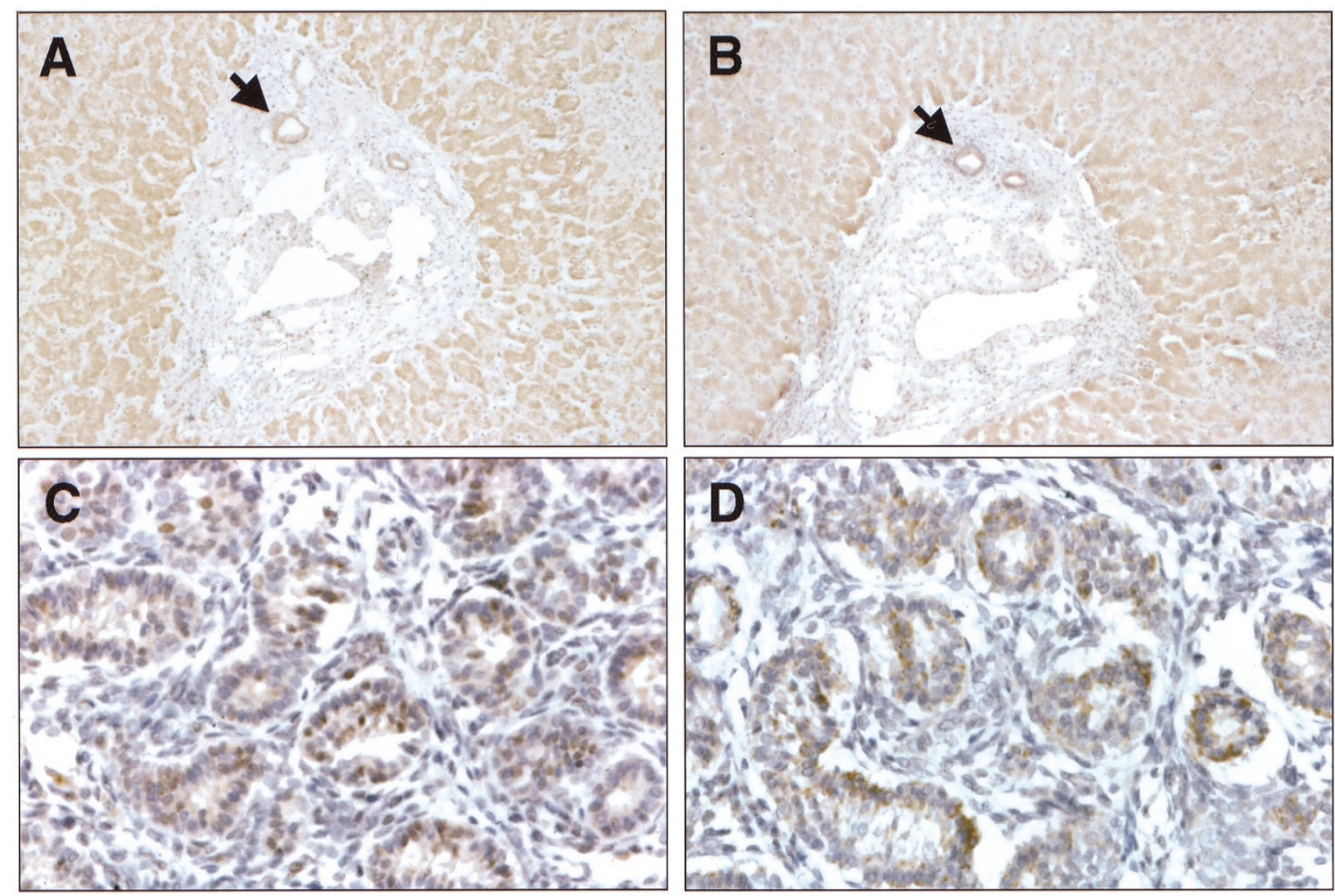

FIGURE 3. Hamartin and tuberin expression in liver and testis of a 3-month-old infant. Sections were stained with anti-hamartin antibody (A, C) and anti-tuberin antibody (B, D). A, B) Serial sections of liver illustrate diffuse cytoplasmic hamartin and tuberin expression in hepatocytes (60×). Note moderate expression in bile ductal epithelium (arrows) and arterioles of the portal tract (center field). C, D) Hamartin and tuberin are both moderately expressed in testis $(250 \times)$. Many spermatagonia and interstitial cells are stained with antisera to both TSC gene products.

the kidney and pancreas-with very high hamartin and comparatively low tuberin immunoreactivity in distal convoluted tubules and a small population of islet cells. Because of the similarity of the antituberin and anti-hamartin staining intensity within other tissues in our study and within other cell types of these same tissues, we believe these data support cell-specific differences in TSC gene product expression and do not reflect relative titers of our antisera. The exact significance of these differences in expression is unclear but may suggest that hamartin expression within some cells is regulated by a mechanism that does not regulate tuberin production. Hamartin may perform a unique function in these cells separate from or in addition to its hypothesized functional interaction with tuberin.

In contrast to results from a previous report (17), we have detected tuberin and hamartin in liver, testis, small and large intestine, and prostate (by immunohistochemical staining of autopsy and surgical tissues) and hamartin in ovary (by Western blot). In support of these findings, we find that tuberin and hamartin are detectable, by Western blot, in homogenates of human hepatocarcinoma and prostatic carcinoma cell lines (21). These data are consistent with previous reports of TSC2 transcript and tuberin localization in human and rat tissues $(13,14,16)$. We were unable to detect fulllength hamartin on immunoblots of homogenates of liver and heart removed at autopsy, although immunohistochemical staining of paraffinembedded materials with our antisera suggests that the proteins are present in these organs. This is not surprising, however, given the postmortem interval of the tissues used for immunoblotting and the propensity of these tissues to autolyze rapidly after death. On the basis of our experience with cultured cells and autopsy tissues, hamartin and tuberin are often degraded unless tissue/cell collection and lysis/homogenization procedures are performed quickly and in the presence of several protease inhibitors. We hypothesize that previous inability by others to detect hamartin in some tissues might have been the result of extensive tissue autolysis.

It is interesting that despite the relatively ubiquitous expression patterns of the TSC gene products, the most common TSC-associated hamartomas are limited to relatively few organs-brain, heart, kidney, and skin. As reported by others (17), this is highlighted by the conspicuous rarity of reports detailing endocrine hamartomas associated with TSC, despite expression of the two gene products in normal endocrine tissues. However, reports of endocrine abnormalities associated with TSC have ap- 

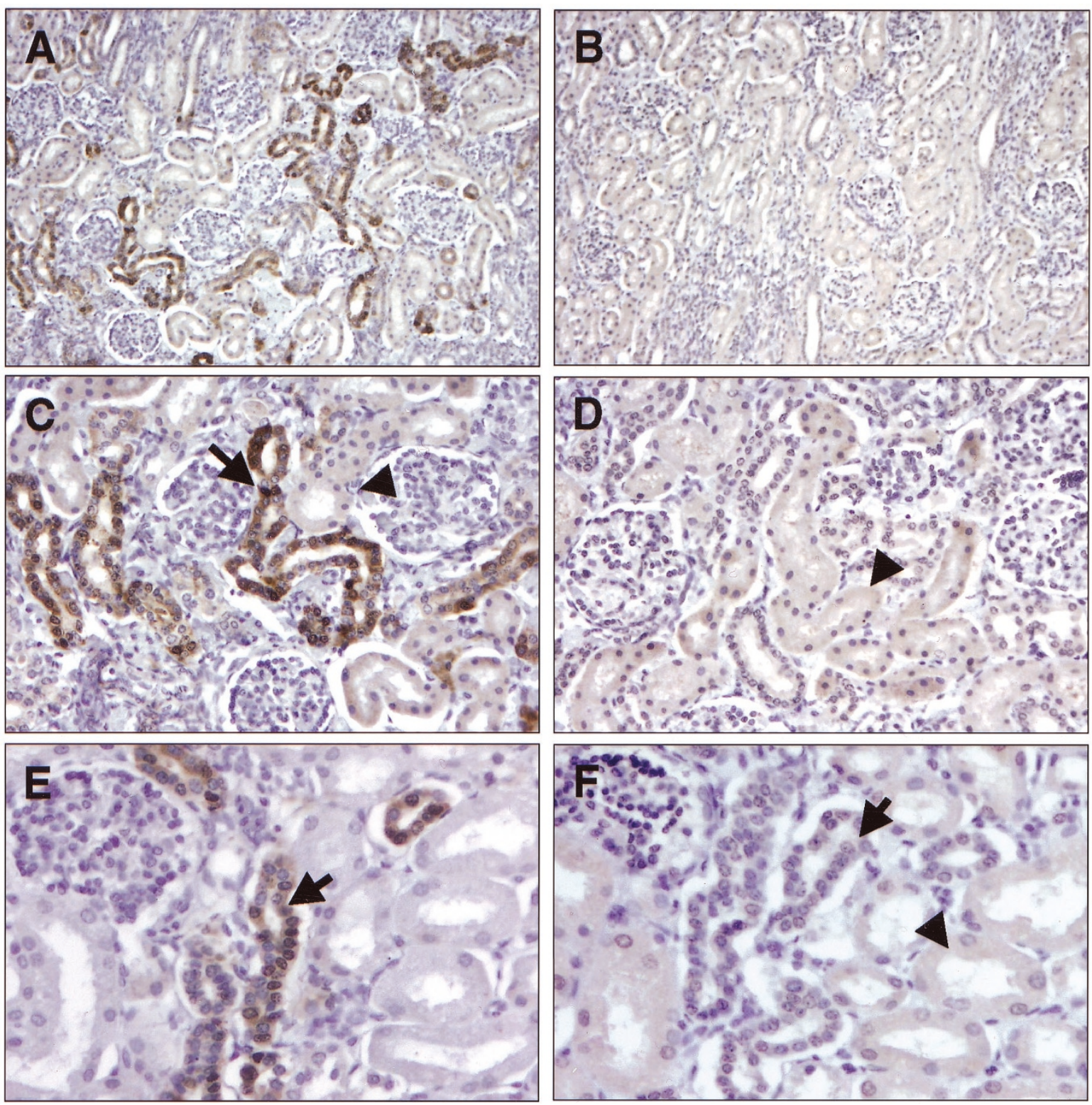

FIGURE 4. Hamartin and tuberin expression in renal cortex. A, B) Differences in hamartin (left) and tuberin (right) expression are obvious within low-magnification fields $(90 \times)$ of the renal cortex of a 1.5-month old. C, D) At higher magnification, moderate hamartin (C) and tuberin (D) expression are noted in proximal convoluted tubules (arrowheads) with obvious brush borders $(170 \times)$. Hamartin expression, however, is very abundant within some cells of the distal convoluted tubules (arrow). E, F) Similar patterns of expression are noted in similar fields within serial sections of the renal cortex of a 3-month-old $(360 \times)$. Note the minimal expression of tuberin $(\mathbf{F})$ as compared with hamartin $(\mathbf{E})$ within distal convoluted tubular epithelium (arrows).

peared. Angiomyolipoma of the adrenal gland, thyroid adenoma, pancreatic islet cell adenoma, pituitary adenoma, angiomyolipoma of the testes, hyperparathyroidism, and hypothalamic/pituitary/ gonadal abnormalities resulting in precocious puberty have all been reported in patients afflicted with TSC (22). Furthermore, there have been rare reports of tumors and hamartomatas associated with TSC in other organs, including liver and intestine (23-27).

Tuberin has been implicated in numerous cell functions, including cell proliferation and cell cycle control and endocytosis $(7,8,14)$. Hamartin inter- acts with and may function with tuberin to affect cell proliferation (28), its purported chaperone (29), and has also been shown to interact with an $\mathrm{N}$-terminal peptide sequence common to ERM proteins (10). However, expression profiles of ERM proteins do not entirely correlate with the distribution of hamartin in all human tissues. For instance, ezrin is expressed highly in proximal convoluted tubules and glomerular epithelium of the human renal cortex but only minimally within the distal convoluted tubules (data not shown). Similar localizations of ezrin and moesin have been reported in the rat kidney (30). These cellular distributions are 

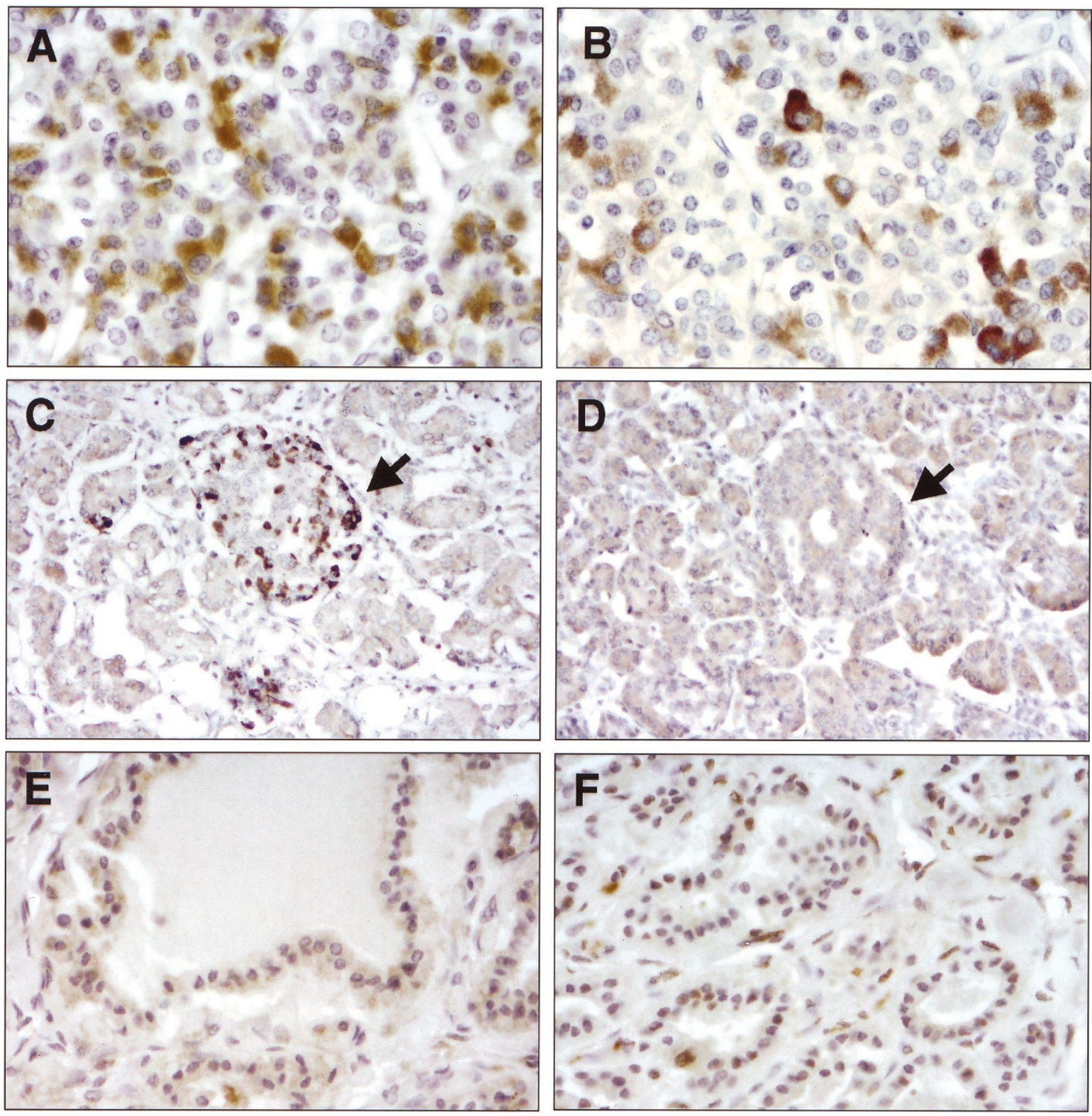

FIGURE 5. Tuberin and hamartin in endocrine tissues. A, B) Hamartin (A) and tuberin (B) are expressed abundantly by many large chromophilic cells in the anterior pituitary of an 8-year-old $(360 \times)$. More cells in comparable sections appear stained with the hamartin antiserum than with antituberin. Smaller cells with little cytoplasm do not appear stained with either antiserum. C, D) Expressions of tuberin and hamartin are compared in similar fields of serial sections from pancreas $(170 \times)$. Tuberin expression (D) is homogeneously moderate throughout acini and islet cells (arrow) from a 3-month-old. Hamartin (C) is also modestly expressed throughout the exocrine pancreas but is robustly expressed within a few islet of Langerhans cells (arrow). E, F) Weak to moderate cytoplasmic hamartin immunoreactivity (E) is found within follicle-lining cells of the thyroid from a 1-year-old. Tuberin immunoreactivity $(\mathbf{F})$ is often more prominent but primarily localized to the nuclei of rare scattered cells (360 $\times$ ).

strikingly different from the localization of hamartin in the kidney. Differences in the expression profiles of hamartin and at least some ERM proteins within human tissues and our data demonstrating differences in tuberin and hamartin cellular expression all support the hypothesis that there may be several cell-specific functions of the TSC gene products. It is likely that because of these complexities in function, it will remain difficult to correlate entirely TSC gene product expression-or loss of expression-with the common clinicopathologic manifestations of tuberous sclerosis.
In conclusion, tuberin and hamartin are coexpressed in most human cell types and tissues. Contrary to a previous report, we have found coexpression of hamartin with tuberin in liver, gut, prostate, and testis and expression of hamartin in ovary. We furthermore describe interesting differences in the cellular expression of the TSC gene product expressions in the kidney and endocrine pancreas, suggesting that hamartin may function in a unique fashion in some cell types of these tissues. Further study of the specific cell types that display differential expression of the TSC gene products 
may provide clues pertinent to the individual functions of the two proteins.

Acknowledgments: We thank Dr. Charles Lassman for his assistance in reviewing immunohistochemical staining of kidney sections. Work was supported in part by a UCLA Molecular and Cellular Neurobiology Training Grant awarded to MWJ.

\section{REFERENCES}

1. Roach ES, Smith M, Huttenlocher P, Bhat M, Alcorn D, Hawley L. Diagnostic criteria: tuberous sclerosis complex. Report of the Diagnostic Criteria Committee of the National Tuberous Sclerosis Association. J Child Neurol 1992;7:221-4.

2. Gomez MR. Phenotypes of the tuberous sclerosis complex with a revision of diagnostic criteria. Ann N Y Acad Sci 1991;615:1-7.

3. Al-Saleem T, Wessner LL, Scheithauer BW, Patterson K, Roach ES, Dreyer SJ, et al. Malignant tumors of the kidney, brain, and soft tissues in children and young adults with the tuberous sclerosis complex. Cancer 1998;83:2208-16.

4. The European Chromosome 16 Tuberous Sclerosis Consortium. Identification and characterization of the tuberous sclerosis gene on chromosome 16. Cell 1993;75:1305-15.

5. van Slegtenhorst $M$, de Hoogt R, Hermans C, Nellist $M$, Janssen B, Verhoef S, et al. Identification of the tuberous sclerosis gene TSC1 on chromosome 9q34. Science 1997;277: 805-8.

6. Wienecke R, König A, DeClue JE. Identification of tuberin, the tuberous sclerosis-2 product. Tuberin possesses specific Rap1GAP activity. J Biol Chem 1995;270:16409-14.

7. Xiao G-H, Shoarinejad F, Jin F, Golemis EA, Yeung RS. The tuberous sclerosis 2 gene product, tuberin, functions as a Rab5 GTPase activating protein (GAP) in modulating endocytosis. J Biol Chem 1997;272:6097-100.

8. Soucek T, Yeung RS, Hengstschlager M. Inactivation of the cyclin-dependent kinase inhibitor p27 upon loss of the tuberous sclerosis complex gene-2. Proc Natl Acad Sci U S A 1998;95:15653-8.

9. van Slegtenhorst M, Nellist M, Nagelkerken B, Cheadle J, Snell R, van den Ouweland A, et al. Interaction between hamartin and tuberin, the TSC1 and TSC2 gene products. Hum Mol Genet 1998;7:1053-1057.

10. Lamb RF, Roy C, Diefenbach TJ, Vinters HV, Johnson MW, Jay DG, et al. The TSC1 tumour suppressor hamartin regulates cell adhesion through ERM proteins and the GTPase Rho. Nat Cell Biol 2000;2:281-287.

11. Green AJ, Smith M, Yates JRW. Loss of heterozygosity on chromosome 16p13.3 in hamartomas from tuberous sclerosis patients. Nat Genet 1994;6:193-6.

12. Carbonara C, Longa L, Grosso E, Borrone C, Garrè MG, Brisigotti M, et al. 9q34 loss of heterozygosity in a tuberous sclerosis astrocytoma suggests a growth suppressor-like activity also for the TSC1 gene. Hum Mol Genet 1994;3:18291832 .

13. Menchine M, Emelin JK, Mischel PS, Haag TA, Norman MG, Pepkowitz SH, et al. Tissue and cell-type specific expression of the tuberous sclerosis gene, TSC2, in human tissues. Mod Pathol 1996;9:1071-9.

14. Wienecke R, Maize JC Jr, Reed JA, de Gunzburg J, Yeung RS, DeClue JE. Expression of the TSC2 product tuberin and its target rap1 in normal human tissues. Am J Pathol 1997;150: 43-50.

15. Mizuguchi M, Kata M, Yamanouchi H, Ikeda K, Takashima S. Tuberin immunohistochemistry in brain, kidneys, and heart with or without tuberous sclerosis. Acta Neuropathol 1997; 94:525-31.

16. Fukuda T, Kobayashi T, Yasui H, Tsutsumi M, Konishi Y, Hino O. Distribution of Tsc2 protein in various normal rat tissues and renal tumours of Tsc2 mutant (Eker) rat detected by immunohistochemistry. Virchows Arch 1999;434:341-50.

17. Plank TL, Logginidou H, Klein-Szanto A, Henske EP. The expression of hamartin, the product of the TSC1 gene, in normal human tissues and in TSC1- and TSC2-linked angiomyolipomas. Mod Pathol 1999;12:539-45.

18. Johnson MW, Emelin JK, Park S-H, Vinters HV. Colocalization of TSC1 and TSC2 gene products in tubers of patients with tuberous sclerosis. Brain Pathol 1999;9:45-54.

19. Murthy V, Haddad LA, Smith N, Pinney D, Tyszkowski R, Brown D, et al. Similarities and differences in the subcellular localization of hamartin and tuberin in the kidney. Am J Physiol Renal Physiol 2000;278:F737-46.

20. Vinters HV, Park SH, Johnson MW, Mischel PS, Catania M, Kerfoot C. Cortical dysplasia, genetic abnormalities and neurocutaneous syndromes. Dev Neurosci 1999;21:248-59.

21. Catania MG, Johnson MW, Liau LM, Kremen TJ, deVellis JS, Vinters HV. Hamartin expression and interaction with tuberin in tumor cell lines and primary cultures. J Neurosci Res 2001;63:276-83.

22. Zimmerman D. The endocrine system in tuberous sclerosis complex. In: Gomez MR, Sampson JR, Whittemore VH, editors. Tuberous sclerosis complex: developmental perspectives in psychiatry. 3rd ed. New York: Oxford University Press: 1999:219-27.

23. Cheung YC, Ng SH, Tan CF, Wong HF, Wan YL. Lymphangiectasia within angiomyolipoma in a tuberous sclerosis patient. Clin Imaging 1999;23:242-4.

24. Hirasaki S, Koide N, Ogawa H, Ujike K, Shinji T, Tsuji T. Tuberous sclerosis associated with multiple hepatic lipomatous tumors and hemorrhagic renal angiomyolipoma. Intern Med 1999;3:345-348.

25. Tsui WM, Colombari R, Portmann BC, Bonetti F, Thung SN, Ferrel LD, et al. Hepatic angiomyolipoma: a clinicopathologic study of 30 cases and delineation of unusual morphologic variants. AM J Surg Pathol 1999;23:34-48.

26. Hizawa K, Lida M, Matsumoto T, Tominaga M, Hirota C, Yao $\mathrm{T}$, et al. Gastrointestinal involvement in tuberous sclerosis. Two case reports. J Clin Gastroenterol 1994;19:46-9.

27. Digoy GP, Tibayan F, Young H, Edelstein P. Adenocarcinoma of the rectum with associated colorectal adenomatous polyps in tuberous sclerosis: a case report. J Pediatr Surg 2000; 35:526-7.

28. Miloloza A, Rosner M, Nellist M, Halley D, Bernaschek G, Hengstschlager M. The TSC1 gene product, hamartin, negatively regulates cell proliferation. Hum Mol Genet 2000;9: 1721-7.

29. Nellist M, van Slegtenhorst MA, Goedbloed M, van den Ouweland AMW, Jalley DJJ, van der Sluijs P. Characterization of the cytosolic tuberin-hamartin complex. J Biol Chem 1999; 274:35647-52.

30. Berryman M, Franck Z, Bretscher A. Ezrin is concentrated in the apical microvilli of a wide variety of epithelial cells whereas moesin is found primarily in endothelial cells. J Cell Sci 1993;105:1025-43. 